J. Pijar MIPA, Vol. VI No.2, September : 39 - 44

ISSN 1907-1744

\title{
MODEL LABORATORIUM VIRTUAL FISIKA MODERN UNTUK MENINGKATKAN KETERAMPILAN GENERIK SAINS MAHASISWA
}

\author{
Gunawan \\ Program Studi Pendidikan Fisika, FKIP Universitas Mataram
}

\begin{abstract}
Abstrak : Telah dikembangkan sebuah model laboratorium virtual untuk perkuliahan fisika modern. Tujuan dari penelitian ini adalah menguji efektivitas model laboratorium virtual fisika modern terhadap keterampilan generik sains mahasiswa. Penelitian ini melibatkan 64 mahasiswa yang terdiri dari 2 kelas, yaitu kelas eksperimen dan kelas kontrol. Instrumen penelitian yang digunakan adalah tes keterampilan generik sains yang terintegrasi dengan penguasaan konsep fisika modern. Data dianalisis menggunakan uji beda rata-rata dan skor gain yang dinormalisasi. Hasil penelitian menunjukkan adanya peningkatan keterampilan generik sains pada kedua kelas. Indikator yang mengalami peningkatan tertinggi adalah kemampuan inferensi logika dan kemampuan membangun konsep. Hasil ini menunjukkan bahwa model laboratorium virtual fisika modern efektif dalam meningkatkan keterampilan generik sains mahasiswa.
\end{abstract}

Kata kunci : Laboratorium Virtual, Fisika Modern, Keterampilan Generik Sains

\section{VIRTUAL LABORATORY MODEL ON MODERN PHYSICS TO INCREASE STUDENTS' SCIENCE GENERIC SKILLS}

\begin{abstract}
We have developed a virtual laboratory model for teaching modern physics. The purpose of this study is to examine the effectiveness of a virtual laboratory model of modern physics on students' generic science skills. The study involved 64 students who were divided into two groups, the experimental group and control group. The research instrument used a generic science skills test that is integrated with the mastery of concepts of modern physics. Data were analyzed by using mean-difference test and normalized gain scores. The results showed an increase in generic science skills in both groups. Indicators showed that the highest increases are logical inference capability and the ability to build concepts. These results indicate that the virtual laboratory model of modern physics is effective to increase students' generic science skills.
\end{abstract}

Keywords : Virtual Laboratory, Modern Physics, Generic Science Skills

\section{PENDAHULUAN}

Salah satu indikator mutu pendidikan di perguruan tinggi adalah prestasi belajar mahasiswa. Prestasi belajar ini dapat dilihat dari nilai akademik yang diperoleh mahasiswa. Nilai akademik ini dipengaruhi oleh beberapa faktor, antara lain proses belajar mengajar. Proses belajar mengajar yang diselenggarakan oleh dosen merupakan faktor yang sangat dominan berpengaruh pada hasil belajar mahasiswa. Oleh karena itu, dosen harus tetap berupaya untuk menyelenggarakan proses belajar yang berkualitas agar mahasiswa dapat mencapai prestasi belajar yang maksimal.

Dalam pembelajaran fisika, faktor lain yang juga mempengaruhi hasil belajar mahasiswa adalah ketersediaan sarana laboratorium, karena praktikum merupakan bagian penting dalam proses pembelajaran fisika. Pelaksanaan praktikum dalam fisika sangat penting dalam rangka mendukung pembelajaran dan memberikan penekanan pada aspek proses. Hal ini didasarkan pada tujuan pembelajaran fisika sebagai proses yaitu meningkatkan kemampuan berpikir peserta didik, sehingga mereka tidak hanya mampu dan terampil dalam bidang psikomotorik, melainkan juga mampu berpikir sistematis, obyektif, dan kreatif. Sinaradi [1] menyatakan bahwa untuk memberikan penekanan lebih besar pada aspek proses, peserta didik perlu diberikan keterampilan seperti mengamati, menggolongkan, mengukur, berkomunikasi, menafsirkan data, dan bereksperimen secara bertahap sesuai dengan tingkat kemampuan berpikir anak dan materi pelajaran yang sesuai dengan kurikulum.
Laboratorium dalam pembelajaran fisika termasuk di LPTK memiliki peranan penting. Diantara peran tersebut diantaranya: Pertama, sebagai wahana untuk mengembangkan keterampilan dasar mengamati atau mengukur dan keterampilan proses lainnya seperti mencatat, membuat tabel, membuat grafik, menganalisis data, menarik kesimpulan, berkomunikasi, dan bekerjasama dalam tim. Kedua, laboratorium sebagai wahana untuk membuktikan konsep atau hukum-hukum alam sehingga dapat lebih memperjelas konsep yang telah dibahas sebelumnya. Ketiga, sebagai wahana mengembangkan keterampilan berpikir melalui proses pemecahan masalah dalam rangka siswa menemukan konsep sendiri. Melalui peran ini laboratorium telah dijadikan wahana untuk learning how to learn [2].

Salah satu matakuliah dalam struktur kurikulum pendidikan fisika di LPTK adalah fisika modern. Fisika modern merupakan salah satu matakuliah penting dalam fisika, karena mendasari beberapa matakuliah lanjutan lainnya diantaranya fisika kuantum, fisika zat padat, fisika statistik dan fisika inti. Secara umum konsep fisika modern meliputi: teori relativitas khusus, teori kuantum untuk radiasi elektromagnetik dan materi, atom-atom serupa hidrogen, atom-atom berelektron banyak, fisika inti, dan sistem-sistem atomik.

Berdasarkan analisis pada materi fisika modern di atas dapat diketahui adanya sejumlah eksperimen yang diperlukan untuk mendukung proses pembelajarannya. Sebaran eksperimen untuk setiap konsep diperlukan untuk mengetahui konsep-konsep mana yang perlu didukung lebih banyak eksperimen. Hal ini dimaksudkan agar model 
J. Pijar MIPA, Vol. VI No.2, September : 39 - 44

virtual laboratory yang dibuat dapat memberikan sumbangan yang lebih besar terhadap perolehan hasil belajar dan tingkat berpikir mahasiswa.

Selain sebaran eksperimen untuk setiap pokok bahasan, hasil analisis konsep-konsep fisika modern menunjukkan bahwa sebagian besar konsep dalam fisika modern termasuk konsep abstrak, sehingga perlu divisualisasikan. Abstraknya konsep dalam fisika modern menyebabkan mahasiswa mengalami kesulitan untuk memahami konsep ini dengan baik. Hal ini menyebabkan rendahnya hasil belajar mahasiswa pada matakuliah fisika modern. Untuk mengatasi kesulitan belajar mahasiswa, pembelajaran fisika modern perlu didukung eksperimen untuk membantu mahasiswa memahami konsep-konsep fisika modern. Masalahnya adalah alat-alat yang diperlukan untuk eksperimen fisika modern sangat terbatas, bahkan tidak tersedia di LPTK. Selain itu, abstraknya konsep dalam fisika modern menyebabkan Untuk mengatasi kesulitan belajar mahasiswa, pembelajaran fisika modern perlu didukung eksperimen untuk membantu mahasiswa memahami konsep-konsep fisika modern. Masalahnya adalah alat-alat yang diperlukan untuk eksperimen fisika modern sangat terbatas, bahkan tidak tersedia di LPTK. Selain itu, abstraknya konsep dalam fisika modern menyebabkan tidak semua eksperimen dapat dilakukan di laboratorium, melalui eksperimen yang nyata. Hal ini menjadi salah satu kendala dalam pembelajaran fisika modern.

Alternatif solusi yang ditawarkan diantaranya melalui pemanfaatan teknologi komputer. Finkelstein [3] mengatakan bahwa komputer dapat digunakan untuk menunjang pelaksanaan praktikum fisika. Tidak hanya dapat digunakan untuk mengumpulkan data, menyajikan, dan mengolah data, komputer juga dapat digunakan untuk memodifikasi eksperimen dan menampilkan eksperimen lengkap dalam bentuk virtual. Garrison [4] menyatakan bahwa teknologi dapat diadaptasi menjadi sebuah pendekatan pembelajaran yang aktif. Perlu perpaduan antara tatap-muka (face to face) dengan pembelajaran online. Beberapa hal yang perlu dipertimbangkan antara pendekatan yang mungkin diterapkan, strategi, teknik, dan peralatan yang ada.

Salah satu bentuk pemanfaatan teknologi komputer dalam pembelajaran fisika modern adalah pengembangan virtual laboratory. Virtual laboratory didefinisikan sebagai suatu bentuk objek multimedia interaktif. Objek multimedia interaktif terdiri dari bermacam format heterogen termasuk teks, hiperteks, suara, gambar, animasi, video, dan grafik. Virtual laboratory merupakan objek multimedia interaktif yang kompleks dan termasuk bentuk digital baru, dengan tujuan pembelajaran implicit atau eksplisit [5]. Dengan teknologi komputer konsepkonsep fisika modern tersebut direalisasikan dalam program komputer dengan menggunakan piranti lunak yang mudah dipelajari. Sejumlah bentuk interaksi dapat dimunculkan melalui media komputer seperti penyajian praktik dan latihan, tutorial, permainan, simulasi, penemuan, dan pemecahan masalah.

Melalui model virtual laboratory mahasiswa diberi tantangan untuk memecahkan masalah dengan versi online atau aplikasi. Yang menarik dari model ini adalah interface pada setiap bagian konten. Laboratorium virtual fokus pada tindakan peserta dalam setting yang realistis. Laboratorium virtual adalah sebuah kesuksesan awal dan momentum pengembangan elemen simulasi (disebut sims) mandiri, dan sekarang melakukan hal yang sama untuk sims dunia virtual [6]. Pembelajaran dengan virtual laboratory menyebabkan mahasiswa lebih mandiri, dapat meningkatkan kemampuan berpikir dan kemampuan mengkomunikasikan idenya [7].

Menurut Brotosiswoyo [8] terdapat 8 macam keterampilan generik sains yang dapat dikembangkan melalui pembelajaran fisika, yang meliputi: (1) pengamatan langsung dan tak langsung; (2) kesadaran tentang skala besaran (sense of scale); (3) bahasa simbolik; (4) kerangka logika taat-asas (logical selfconsistency) dari hukum alam; (5) inferensi logika; (6) hukum sebab-akibat (causality); (7) pemodelan matematik; dan (8) membangun konsep.

Melalui delapan macam keterampilan generik sains orang dapat mengembangkan keterampilan berpikir tingkat tinggi. Berpikir kritis banyak dikembangkan apabila seseorang melakukan pengamatan langsung dan tak langsung, menyadari akan skala besaran, membuat pemodelan matematik, dan membangun konsep. Berpikir kreatif diterapkan ketika seseorang merumuskan bahasa simbolik, inferensi logika, dan menemukan kerangka logika taat-asas dari hukum alam. Berpikir pemecahan masalah diterapkan apabila seseorang sedang menyelidiki berlakunya hukum sebab-akibat pada sejumlah gejala alam yang diamatinya. Selanjutnya pengambilan keputusan dapat digunakan orang ketika membangun konsep, membuat pemodelan matematik, dan menemukan inferensi logika. Dengan demikian apabila orang hanya mempelajari sains dari segi terminologinya saja apalagi secara hafalan, maka berarti pula ia tidak belajar sains [9].

Pembelajaran fisika modern yang didukung model virtual laboratory diharapkan dapat meningkatkan keterampilan generik sains mahasiswa calon guru. Beberapa penelitian pembelajaran fisika berbantuan komputer menunjukkan adanya korelasi positif antara media pembelajaran komputer dengan penguasaan konsep dan keterampilan generik sains mahasiswa. Gunawan [10] menemukan bahwa model multimedia interaktif dalam pembelajaran fisika dasar dapat meningkatkan keterampilan generik sains mahasiswa calon guru, dimana indikator pengamatan tidak langsung mengalami peningkatan tertinggi. McKagan [11] menemukan bahwa penggunaan simulasi komputer pada materi mekanika kuantum dapat meningkatkan hasil belajar dan aktivitas mahasiswa di kelas. Penggunaan simulasi komputer membantu mahasiswa mengatasi kesulitan belajarnya pada materi ini. Gunawan [12] menemukan bahwa penggunaan virtual laboratory fisika modern juga dapat meningkatkan penguasaan konsep mahasiswa calon guru, khususnya pada konsep teori kuantum radiasi elektromagnetik dan materi.

Pada penelitian ini telah dikembangkan suatu model virtual laboratory fisika modern sebagai solusi alternatif terbatasnya fasilitas laboratorium dan kesulitan eksperimen pada konsep fisika modern yang abstrak. 
Model virtual laboratory ini diharapkan dapat meningkatkan keterampilan generik sains calon guru. Dalam makalah ini akan dijelaskan efektivitas penggunaan model virtual laboratory fisika modern terhadap peningkatan keterampilan generik sains mahasiswa fisika.

\section{METODE PENELITIAN}

Penelitian ini termasuk jenis penelitian dan pengembangan (research and development). Metode penelitian dan pengembangan adalah suatu metode yang digunakan untuk menghasilkan produk tertentu dan menguji keefektivan produk tersebut [13]. Dalam penelitian ini telah dikembangkan suatu model virtual laboratory untuk pembelajaran fisika modern. Untuk pengujian efektivitas model virtual laboratory terhadap peningkatan keterampilan generik sains mahasiswa digunakan metode eksperimen dengan pretest-posttest control group design. Untuk memperoleh data penelitian digunakan instrumen tes keterampilan generik sains yang terintegrasi dengan penguasaan konsep fisika modern.

Keterampilan generik sains mahasiswa dinilai dari jawaban tes awal dan tes akhir mahasiswa setelah mengikuti pembelajaran. Untuk mengetahui peningkatan keterampilan generik sains mahasiswa calon guru dilakukan dengan menghitung besarnya skor gain yang dinormalisasi (N-gain). Hal ini dimaksudkan untuk menghindari kesalahan dalam menginterpretasikan perolehan gain masing-masing mahasiswa. Untuk memperoleh skor N-gain digunakan rumus [14]:

$$
\mathrm{N} \text { - gain }=\frac{\mathrm{S}_{\text {post }}-\mathrm{S}_{\text {pre }}}{\mathrm{S}_{\max }-\mathrm{S}_{\text {pre }}} \times 100 \%
$$

Tabel 1. Kategori Skor N-gain

\begin{tabular}{|c|c|}
\hline $\mathrm{N}$-gain & Kategori \\
\hline $\mathrm{N}$-gain $>70 \%$ & Tinggi \\
\hline $30 \%=\mathrm{N}$-gain $=70 \%$ & Sedang \\
\hline $\mathrm{N}$-gain $<30 \%$ & Rendah \\
\hline
\end{tabular}

Pengolahan data penelitian diawali dengan uji statistik berupa uji normalitas dan uji homogenitas. Selanjutnya dilakukan uji perbedaan dua rerata untuk menguji tingkat signifikasi perbedaan rerata skor tes keterampilan generik sains kedua kelas (kelas eksperimen dan kelas kontrol).

\section{HASIL IMPLEMENTASI MODEL VIRTUAL LABORATORY}

Berdasarkan analisis data pada perolehan skor keterampilan generik sains mahasiswa calon guru, dapat diketahui adanya peningkatan keterampilan generik sains pada kedua kelas. Hasil penilaian keterampilan berupa skor yang kemudian dicari persentasenya. Perolehan skor ratarata tes awal, tes akhir, dan $\mathrm{N}$-gain keterampilan generik sains pada kelas eksperimen dan kelas kontrol dapat dilihat pada Tabel 2.
Tabel 2. Deskripsi Skor Keterampilan Generik Sains Mahasiswa Kedua Kelas

\begin{tabular}{|l|c|c|c|c|c|c|}
\hline \multirow{2}{*}{} & \multicolumn{3}{|c|}{ Kelas Eksperimen } & \multicolumn{3}{c|}{ Kelas Kontrol } \\
\cline { 2 - 7 } & $\begin{array}{c}\text { Tes } \\
\text { Awal }\end{array}$ & $\begin{array}{c}\text { Tes } \\
\text { Akhir }\end{array}$ & N-g & $\begin{array}{c}\text { Tes } \\
\text { Awal }\end{array}$ & $\begin{array}{c}\text { Tes } \\
\text { Akhir }\end{array}$ & N-g \\
\hline $\begin{array}{l}\mathrm{N}(\Sigma \\
\text { mahasiswa) }\end{array}$ & 32 & 32 & & 32 & 32 & \\
\hline Rata-rata & 30,31 & 69,06 & 56,53 & 30,42 & 58,96 & 41,24 \\
\hline $\begin{array}{l}\text { Simpangan } \\
\text { Baku }\end{array}$ & 9,50 & 13,20 & 15,90 & 8,80 & 13,87 & 18,50 \\
\hline
\end{tabular}

Berdasarkan Tabel 2 dapat diketahui bahwa skor rata-rata tes awal mahasiswa pada kedua kelas hampir sama. Hasil uji beda rerata pada skor tes awal menunjukkan nilai $\mathrm{t}_{\text {hitung }}$ sebesar 0.048 dan $\mathrm{t}_{\text {tabel }}$ pada taraf kepercayaan 0,05 sebesar 1,68. Dari hasil ini dapat disimpulkan bahwa keterampilan generik sains mahasiswa sebelum proses pembelajaran pada kedua kelas tidak berbeda secara signifikan.

Selanjutnya berdasarkan perolehan skor tes akhir pada kedua kelas, diketahui bahwa skor rata-rata tes akhir kelas eksperimen sebesar 69,06 dan kelas kontrol sebesar 58,96 . Peningkatan pada kelas eksperimen dengan skor rata-rata sebesar 56,53\% sedangkan untuk kelas kontrol sebesar $41,24 \%$. Kedua kelas mengalami peningkatan dengan kategori sedang. Hal ini menunjukkan bahwa keterampilan generik sains mahasiswa setelah mengikuti pembelajaran secara umum mengalami peningkatan dimana keterampilan generik sains mahasiswa pada kelas eksperimen lebih baik dibandingkan dengan mahasiswa pada kelas kontrol.

Selanjutnya dilakukan uji beda rerata skor $\mathrm{N}$-gain kedua kelas untuk mengetahui signifikansi perbedaan peningkatan keterampilan generik sains kedua kelas. Hasil uji-t menunjukkan nilai $t_{\text {hitung }}$ sebesar 4.41 dan $t_{\text {tabel }}$ pada taraf kepercayaan 0,05 sebesar 2.04. Dari hasil ini dapat disimpulkan bahwa terdapat perbedaan peningkatan keterampilan generik sains mahasiswa yang signifikan antara kelas eksperimen dengan kelas kontrol, dimana keterampilan generik sains mahasiswa kelas eksperimen lebih baik dibandingkan dengan kelas kontrol. Persentase pencapaian skor rata-rata tes awal, tes akhir, dan N-gain keterampilan generik sains antara kelas eksperimen dan kelas kontrol ditampilkan pada Gambar 1.

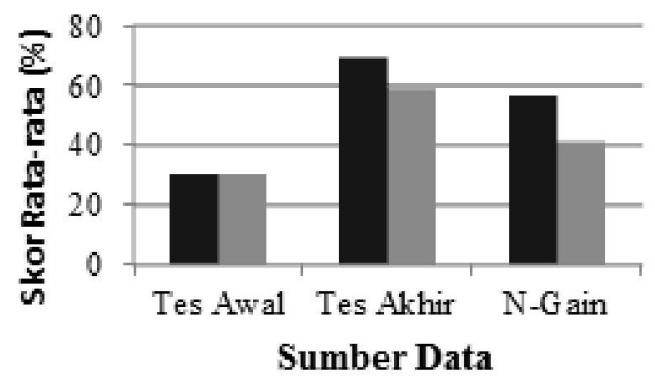

- Kelas Eksperim en $\quad$ Kelas Kontrol

Gambar 1. Perbandingan Persentase Skor Rata-rata KGS Kedua Kelas 
J. Pijar MIPA, Vol. VI No.2, September : 39 - 44

Setiap indikator keterampilan generik sains dianalisis ketercapaiannya berdasarkan perolehan skor tes awal, tes akhir, dan N-gain. Perolehan N-gain tertinggi kelas kontrol terjadi pada indikator kemampuan membangun konsep sebesar $47,5 \%$ dengan kategori sedang dan skor N-gain terendah terjadi pada indikator inferensi logika sebesar 26,5\% dengan kategori rendah, sedangkan perolehan $\mathrm{N}$-gain tertinggi kelas eksperimen terjadi pada indikator kemampuan membangun konsep $62,9 \%$ dan skor $\mathrm{N}$-gain terendah terjadi pada indikator hubungan sebab akibat sebesar $48,6 \%$ pada kategori sedang. Rekapitulasi skor keterampilan generik sains untuk setiap indikator ditampilkan pada Tabel 3.

Tabel 3. Rekapitulasi Skor Keterampilan Generik Sains Setiap Indikator

\begin{tabular}{|c|c|c|c|}
\hline \multirow{2}{*}{ Indikator } & \multicolumn{2}{|c|}{ Persentase Skor N-gain } & \multirow{2}{*}{$0<\mathrm{g}>$} \\
\cline { 2 - 3 } & $\begin{array}{c}\text { Kelas } \\
\text { Eksperimen }\end{array}$ & $\begin{array}{c}\text { Kelas } \\
\text { Kontrol }\end{array}$ & \\
\hline $\begin{array}{c}\text { KGS 1: Pengamatan Tidak } \\
\text { Langsung }\end{array}$ & 61.2 & 41.9 & 19.3 \\
\hline $\begin{array}{c}\text { KGS 2: Kesadaran akan Skala } \\
\text { Besaran }\end{array}$ & 57.2 & 44.1 & 13.1 \\
\hline KGS 3: Inferensi Logika & 52.1 & 26.5 & 25.6 \\
\hline $\begin{array}{c}\text { KGS 4: Hukum Sebab } \\
\text { Akibat }\end{array}$ & 48.6 & 31.2 & 17.4 \\
\hline $\begin{array}{c}\text { KGS 5: Pemodelan } \\
\text { Matematis }\end{array}$ & 49.7 & 28.0 & 21.7 \\
\hline KGS 6: Membangun Konsep & 62.9 & 47.5 & 15.4 \\
\hline
\end{tabular}

Dari Tabel 3 dapat diketahui bahwa perbedaan peningkatan $\mathrm{N}$-gain tertinggi pada kedua kelas terjadi pada indikator inferensi logika sebesar $25,6 \%$ sedangkan perbedaan terendah pada indikator kesadaran akan skala besaran sebesar 13,1\%. Persentase keterampilan generik sains mahasiswa kedua kelas pada masing-masing indikator keterampilan generik sains ditampilkan pada Gambar 2.

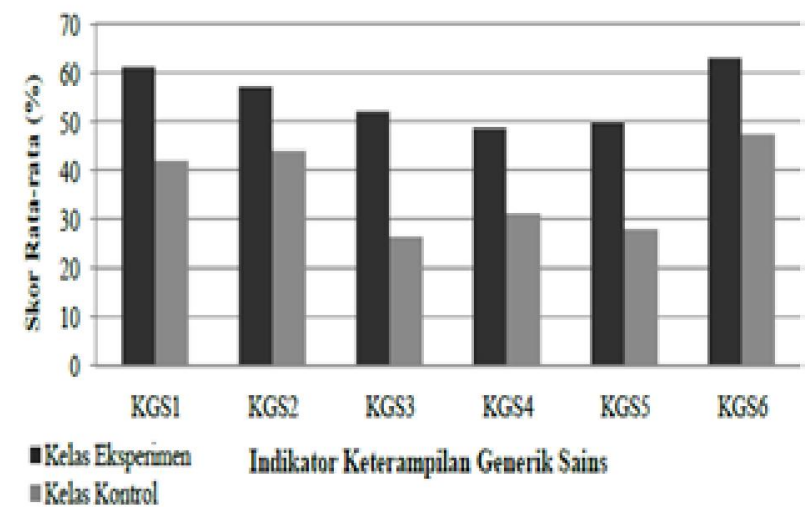

Gambar 2. Perbandingan Persentase N-Gain untuk Setiap Indikator KGS

Berdasarkan persentase peningkatan keterampilan generik sains dapat diketahui bahwa terjadi peningkatan pada kedua kelas. Meskipun demikian persentase peningkatan keterampilan generik sains mahasiswa kelas eksperimen lebih tinggi dibandingkan mahasiswa kelas kontrol. Artinya bahwa pembelajaran fisika modern dengan virtual laboratory dapat meningkatkan keterampilan generik sains mahasiswa calon guru lebih baik dari pembelajaran konvensional.

\section{PEMBAHASAN}

Dalam pembelajaran dengan model virtual laboratory fisika modern yang telah dilakukan terdapat keterampilan generik sains yang dikembangkan. Dalam penelitian ini kemampuan generik sains yang dikembangkan adalah pengamatan tidak langsung, kesadaran akan skala besaran, inferensi logika, hukum sebab akibat, pemodelan matematik, dan kemampuan membangun konsep. Pemilihan indikator ini didasarkan pada pertimbangan karakteristik materi fisika modern, khususnya pada konsep teori kuantum radiasi elektromagnetik dan materi.

Dari data yang diperoleh dapat diketahui bahwa terjadi peningkatan keterampilan generik sains mahasiswa baik yang diajarkan secara konvensional maupun yang belajar dengan virtual laboratory. Dari rata-rata N-gain dapat diketahui bahwa peningkatan keterampilan generik sains mahasiswa kelas eksperimen lebih tinggi dibandingkan kelas kontrol. Berdasarkan analisis uji-t pada setiap indikator juga dapat diketahui bahwa perbedaan peningkatan keterampilan generik sains kedua kelas untuk setiap indikator berbeda secara signifikan.

Peningkatan keterampilan generik tertinggi kelas eksperimen maupun kelas kontrol terjadi pada indikator kemampuan membangun konsep dengan peningkatan masing-masing 62,9\% (kelas eksperimen) dan 47,5\% (kelas kontrol), keduanya berada pada kategori sedang. Sedangkan peningkatan terendah terjadi pada indikator hukum sebab akibat sebesar 48,6\% (kelas eksperimen) dan indikator inferensi logika sebesar 26,5\% (kelas kontrol). Peningkatan tertinggi yang terjadi pada indikator kemampuan membangun konsep menunjukkan bahwa model pembelajaran yang diterapkan terbukti mampu mendorong mahasiswa untuk belajar menemukan dan menyimpulkan sendiri konsep-konsep penting yang dipelajari.

Perbedaan perolehan N-Gain tertinggi untuk kedua kelas terdapat pada indikator kemampuan inferensi logika yaitu sebesar $25,6 \%$. Hal ini dapat dipahami karena mahasiswa kelas eksperimen terbiasa dalam penggunaan logika dalam menyelesaikan permasalahan yang dihadapi ketika melakukan eksperimen maupun ketika bekerja mengisi lembar kerja mahasiswa. Terdapat beberapa hal yang kemudian disimpulkan sendiri oleh mahasiswa ketika mereka menggunakan pendekatan logis yang sama untuk menyelesaikan suatu permasalahan. Misalnya ketika mahasiswa melakukan eksperimen efek fotolistrik, mahasiswa berkesempatan melakukan eksplorasi fitur dan menu-menu yang disediakan dalam software. Hasilnya mahasiswa dapat menyimpulkan bahwa tidak semua jenis bahan yang disinari akan memancarkan elektron. Sedangkan pada kelas kontrol yang belajar secara konvensional hanya disuguhkan sejumlah informasi, berdiskusi dan tutorial. Mereka tidak berkesempatan melakukan eksplorasi yang mendorong keingintahuan dan penalarannya. Hal ini menunjukkan betapa pentingnya 
Model Laboratorium Virtual Fisika Modern Untuk Meningkatkan Keterampilan Generik ..... (Gunawan)

peranan kegiatan eksperimen dalam mendukung pembelajaran fisika, khususnya fisika modern.

Perbedaan peningkatan N-Gain paling rendah terjadi pada indikator kesadaran akan skala besaran, dengan nilai sebesar $13,07 \%$. Hal ini dapat dipahami karena konsep-konsep dalam fisika modern, khususnya pada materi teori kuantum radiasi melibatkan banyak sekali konstanta atau tetapan yang nilainya beragam mulai dari kecepatan cahayayang tinggi $\left(\mathrm{c}=3 \times 10^{8} \mathrm{~m} / \mathrm{s}\right)$ hingga tetapan Planck $\left(\mathrm{h}=6.626068 \times 10^{-34} \mathrm{~m}^{2} \mathrm{~kg} / \mathrm{s}\right)$ yang sangat kecil. Selain besaran di atas, pada topik ini terdapat sejumlah besaran lainnya yang juga menuntut ketelitian dalam penulisan dan perhitungan.

Karena besaran dengan skala yang beragam itu merupakan bagian yang tidak terpisahkan dalam konsep fisika modern, khususnya teori kuantum radiasi, maka pembelajaran dengan model apapun pasti akan melibatkan skala-skala tersebut. Dengan kata lain, pembelajaran fisika modern baik secara konvensional maupun dengan model pembelajaran dengan pemanfaatan virtual laboratory pasti akan memberikan penekanan pada pentingnya kesadaran akan skala besaran tersebut dalam pemahaman konseptual maupun dalam perhitungan matematis, sehingga sangat wajar jika perbedaan N-Gain pada indikator kesadaran akan skala besaran tidak terlalu besar pada kedua kelas.

Peningkatan N-Gain yang lebih besar pada indikator inferensi logika dan kemampuan membangun konsep disebabkan karena model pembelajaran yang telah dibuat menyajikan beberapa animasi dan simulasi interaktif dimana mahasiswa banyak dilatih untuk membuat perkiraan-perkiraan yang logis dari suatu permasalahan. Selain terbiasa dengan penalaran logis, simulasi interaktif yang ada juga mengarahkan mahasiswa untuk menemukan konsep sendiri.

Hasil di atas sejalan dengan hasil penelitian sebelumnya yang dilakukan Gunawan [10] yang menemukan bahwa penggunaan model pembelajaran berbasis multimedia interaktif pada perkuliahan fisika dasar pada konsep elastisitas dapat meningkatkan kemampuan inferensi logika dan kemampuan membangun konsep calon guru fisika. Gilbert [15] menemukan bahwa animasi pada level molekular dapat membantu mahasiswa membuat model mental yang akurat untuk menjelaskan observasi di laboratorium serta pemahaman simbolis yang lebih dalam. Gunawan [12] menemukan bahwa melalui model virtual laboratory fisika dapat meningkatkan penguasaan konsep mahasiswa. Beberapa materi yang tergolong sulit dan abstrak seperti radiasi termal dan difraksi elektron mengalami peningkatan $\mathrm{N}$-gain yang signifikan.

Penjelasan di atas menunjukkan bahwa selain dapat meningkatkan penguasaan konsep dan keterampilan generik sains mahasiswa, model virtual laboratory fisika modern dapat dijadikan alternatif untuk tetap bisa melakukan eksperimen fisika modern. Selain lebih murah dan terjangkau, juga lebih aman bagi mahasiswa sebagai pengguna. Mahasiswa berkesempatan melakukan eksperimen dimanapun dan kapanpun sesuai kebutuhannya.

Selain beberapa temuan di atas, pembelajaran fisika modern yang didukung virtual laboratory memberikan penekanan pada keterampilan berpikir mahasiswa. Terdapat beberapa keuntungan yang diperoleh dari proses belajar mengajar yang telah dilakukan antara lain 1) belajar lebih ekonomis, artinya bahwa apa yang diperoleh dari proses pembelajaran akan bertahan lama dalam benak mahasiswa, 2) cenderung menambah motivasi belajar baik pada dosen maupun mahasiswa, 3) mahasiswa mempunyai sikap ilmiah, karena dibiasakan berpikir dan melakukan sesuatu sesuai prinsip dan metode ilmiah dan 4) mahasiswa mempunyai kemampuan memecahkan masalah, baik pada saat pembelajaran di kelas maupun dalam permasalahan nyata dalam kehidupan sehari-hari [16].

\section{KESIMPULAN}

Berdasarkan hasil penelitian dapat disimpulkan bahwa keterampilan generik sains mahasiswa yang memperoleh perlakuan pembelajaran dengan virtual laboratory lebih tinggi dibandingkan dengan mahasiswa yang diajarkan secara konvensional. Dengan model pembelajaran ini kemampuan inferensi logika dan kemampuan membangun konsep dapat lebih ditingkatkan. Peningkatan tertinggi pada indikator kemampuan membangun konsep, sedangkan terendah pada indikator kesadaran akan skala besaran. Inferensi logika merupakan indikator yang mengalami perbedaan peningkatan tertinggi pada kedua kelas.

\section{Rekomendasi}

Berdasarkan hasil penelitian dan pembahasan yang telah dilakukan, peneliti merekomendasikan agar model pembelajaran dengan virtual laboratory dilengkapi dengan buku petunjuk penggunaan software sehingga mahasiswa dapat lebih mudah menggunakannya. Selain itu, diperlukan penjelasan tambahan tentang tahapan-tahapan percobaan yang dapat dilakukan agar lebih mengarahkan mahasiswa untuk memahami konsep fisika modern dengan lebih baik. Penelitian ini berfokus kepada enam indikator keterampilan generik sains, sehingga masih diperlukan penelitian lanjutan khususnya pada beberapa indikator dengan peningkatan yang masih rendah. Perlunya pertimbangan untuk kemungkinan akses materi secara online sebagai alternatif penelitian lebih lanjut.

\section{Ucapan Terima Kasih}

Penulis menyampaikan ucapan terima kasih yang sebesar-besarnya kepada yth Ibu Prof. Dr. Liliasari, M.Pd (SPs UPI), Dr. Agus Setiawan, M.Si (FPTK UPI), Dr. Dwi Widyantoro, M.Sc (Teknik Informatika ITB) yang telah banyak memberikan masukan dan tinjauan kritis guna penyempurnaan tulisan ini.

\section{DAFTAR PUSTAKA}

[1] Sinaradi, F. (1998). "Menguji Kualitas Barang: Suatu Alternatif Model Pengajaran Sains", dalam Pendidikan Sains yang Humanistis. Yogyakarta: Kanisius.

[2] Wiyanto. (2008). Menyiapkan Guru Sains Mengembangkan Kompetensi Laboratorium. Semarang: Universitas Negeri Semarang Press. 
J. Pijar MIPA, Vol. VI No.2, September : 39 - 44

[3] Finkelstein. (2005). "When Learning About the Real World Is Better Done Virtually: A Study of Subtituting Computer Simulations for Laboratory Equipment". Physics Education Research. APS (1) $1-8$.

[4] Garrison, D.R \& Vaughan, N.D., (2008). Blended Learning in Higher Education. San Fransisco : John Willey \& Sons, Inc.

[5] Budhu, M. (2002). Virtual Laboratories for Engineering Education. Paper presented at International Conference on Engineering Education. Manchester, U.K,. August 18-21, 2002.

[6] Aldrich, C. (2009). Learning Online with Games, Simulations, and Virtual Worlds. San Fransisco: John Wiley \& Sons, Inc.

[7] Smith, I. D. (2002). Enhancing thinking and Communication Skills through Project Work. Singapore: Prentice Hall.

[8] Brotosiswoyo, B. S (2001). Hakekat Pembelajaran MIPA di Perguruan Tinggi: Fisika. Jakarta: PAUPPAI Dirjen Dikti Depdiknas.

[9] Liliasari, (2007). "Scientific Concepts and Generic Science Skills Relationship In The 21st Century Science Education", dalam Proceeding The First International Seminar on Science Education, Bandung: Program Pendidikan IPA SPs UPI.

[10] Gunawan. (2009). "Pembelajaran Berbasis Multimedia Interaktif untuk Meningkatkan Keterampilan Generik Sains Calon Guru Fisika". Jurnal PIJAR MIPA. Vol 4. No. 2, 46 - 49

[11] McKagan et al. (2008). "Developing and Researching PhET simulations for Teaching Quantum Mechanics". American Journal of Physics (76) 406 $-417$

[12] Gunawan \& Setiawan, A. (2010). "Using Virtual Laboratory to Increase Students' Understanding on Modern Physics", dalam Proceeding The $4^{\text {th }}$ International Seminar on Science Education, Bandung: Program Pendidikan IPA SPs UPI.

[13] Sugiyono. (2008). Metode Penelitian Pendidikan: Pendekatan Kuantitatif, Kualitatif, dan R\&D. Bandung: Alfabeta.

[14] Cheng, K. (2004). "Using Online Homeworks Systems Enhances Student. Learning of Physics Concept in an Introductory Physics Course". American Journal of Physics. 72 (11) 1447-1453.

[15] Gilbert, J.K. (2008). Visualization: Theory and Practice in Science Education. USA: Springer

[16] Wahidin, D. (1996). "Berpikir Kreatif dan Perkembangannya dalam Pengajaran IPA". Khazanah Pengajaran IPA 1 (2) : 23-31. 